\title{
SZÜCS Krisztián
}

\section{MARKETINGKUTATÁS 2.0}

\author{
KORREFERÁTUM SIMON JUDIT „KUTATÁS-MÓDSZERTANI \\ TRENDEK A MARKETINGBEN” CÍMÜ TANULMÁNYÁHOZ
}

\begin{abstract}
Az aktuális trendek felismerése igazi szakmai kihívás, hiszen a változásokat megélve kell azokat a jelenségeket tendenciává összerendezni, amelyek a közelmúltban gyökerezve a jövő́t alakítják. Jelen tanulmány kísérletet tesz arra, hogy összefoglalja a marketingkutatás területén bekövetkezett fontosabb változásokat és ezekből kirajzolja azokat a jövơbeli irányokat, amelyek egy új üzleti múködés alapjai lehetnek.
\end{abstract}

\section{Kulcsszavak: marketingkutatás, trendek, múködési modell}

A közelmúlt változásait, azok jövőbeli következményeit megítélni a legtöbb esetben kockázatos, mégis szükségszerú. Jelen tanulmányban az elmúlt egy, másfél évtized során a marketingkutatás módszertanában bekövetkezett irányváltásokat fogjuk összegyújteni, részben reflektálva és építkezve más munkákra, részben pedig egy új közelítést ${ }^{1}$ bemutatva, amelynek fókuszában a korábbi üzleti modellt felváltó megoldás áll.

A XXI. század elejét meghatározó legfontosabb változás kétségkívül az információtechnológiai fejlődés kiteljesedése, illetve az ennek következtében tovagyưrüző hatások eredőjeként kialakult gazdasági válság volt. Ezek a hatások természetszerúleg érintették a marketingkutatási iparágat is, radikális változásokat előidézve, amelyre az akadémiai közeg érdemben mind a mai napig nem reagált.

Bizonyítja ezt az elmúlt években a témában megjelent tudományos publikációk alacsony száma itthon és külföldön egyaránt, illetve a jelen tanulmány kiindulópontjának is tekinthető összefoglalóban (Simon, 2016) megtalálható aktuálisan érvényes definíció az Amerikai Marketing Szövetség (AMA) megfogalmazásában. A változások összefoglalásának kiindulópontjaként kezelt Malhotra és Peterson cikk (2001) legtöbb megállapítása kétségkívül mind a mai napig érvényes, amelyek akkor még előrejelzésként funkcionáltak, napjainkra inkább már beigazolódott tényként kezelhetők.

\section{Az alkalmazott közelítés}

A megváltozott fogyasztói magatartás folyamatosan új kihívásokat jelent a marketingkutatók számára (Mal- hotra - Simon, 2009), hiszen az objektív információk összegyújtésekor

- új csatornákat, adatfelvételi megoldásokat kell használni,

- szembesül a kutató azzal, hogy sok esetben a fogyasztó maga sem tudja indokolni, miért (úgy) hozta meg az adott döntést.

Ez pedig jelentôs frusztrációt okoz a megbízói oldalon is, hiszen elkerülhetetlen, hogy a marketing-szakemberek megfeleló információkkal rendelkezzenek a piacról, a fogyasztókról. A fentiek alapján ez az elvárás az utóbbi évtizedben egyre komolyabb kérdéseket vet fel, így például a marketingkutatás módszertani eszköztárának hatékonyságával kapcsolatban. Miután egyre inkább megkérdőjeleződik a megbízhatósága azoknak a megoldásoknak, amiket korábban erre a célra a kutatók alkalmaztak (Zolli, 2006), szükség van olyan új megközelítésekre, amelyek mind a megbízók igényeit és elvárásait, mind a fogyasztók megváltozott szokásait figyelembe veszik.

Egy korábbi tanulmányban (Szúcs, 2013) tett megállapításunk szerint „érdekes jelenség figyelhető meg a legtöbb piacon: az információ értéke egyik oldalról folyamatosan és megállíthatatlanul növekszik, de egy másik aspektusból vizsgálva gyakorlatilag eltúnt. Lehet ez azért, mert a vállalati felhasználók számára mindennél fontosabbá (és így értékesebbé) vált megismerni a célpiacot, a vásárlási döntéseket alakító preferenciákat, míg a fogyasztók (főleg a fiatalabb generáció tagjai) szívesen és leginkább ingyenesen osztanak meg információt egymással, vagy akár a »nagyvilággal«". 
Talán ez alkalommal valódi paradigmaváltás zajlik a marketingkutatásban, számos új technika, megoldás jelenik meg a gyakorlatban és bár kisebb részben, de az elméleti publikációkban is (ld. például Malhotra - Peterson, 2001; Grover - Vriens, 2006). Mindezek a változások természetesen egy nagyobb folyamat részei, következményei, amelyeket alapvetően az aktuális fogyasztói magatartás trendjei vezérelnek (Törőcsik, 2011). Fletcher (2006) a töredezett társadalmi szerkezetre és az ezzel járó információgyújjtési nehézségekre, míg Gordon (2006) olyan alapvetésekre hívja fel a figyelmet, amelyek alapjaiban kérdőjelezik meg a hagyományos adatfelvételi megoldások megbízhatóságát.

\section{A marketingkutatás klasszikus és új modellje}

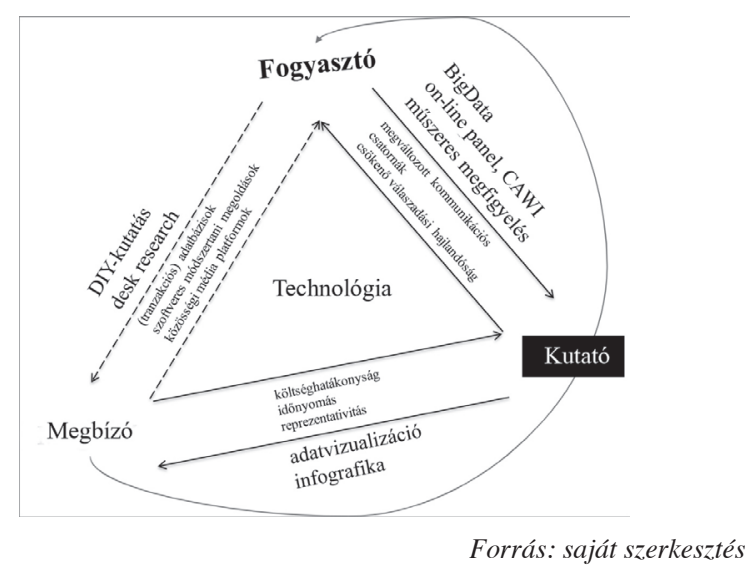

Korábban nem tapasztalt feszültség érzékelhetô a fentiek miatt a kutatási projektekben érintett felek között, akik új korlátokkal és lehetőségekkel szembesülnek, így az alapvető keretek változása zajlik jelenleg is. Vagyis a megváltozott körülmények között új elvárások jelentek meg a megbízók részéról, ezzel párhuzamosan pedig újfajta korlátok (és egyben lehetőségek) a fogyasztók részéről, nyilvánvalóan ezekhez a kutatóknak alkalmazkodniuk szükséges. (1.ábra)

A klasszikus múködési alapelvek az elmúlt években egyre inkább megkérdőjeleződnek, hiszen:

- a gazdasági válság hatásaként a kutatási iparág árbevétele is csökkenő tendenciát mutat(ott), ami részben annak is betudható, hogy a megnövekedett költséghatékonysági elvárásokat a tradicionális eszköztár alkalmazásával a kutatók már nem tudták biztosítani, mivel így a megtérülés vált elsődleges teljesítményindikátorrá (Chadwick, 2006), a kutatási eredmények előállítására fordítható idő és anyagi erôforrás minden korábbinál szúkösebbé vált, miközben még nagyobb proaktivitást, in- volváltságot és ezzel együtt kiterjedt tanácsadási szolgáltatást várnak el az ügyfelek,

- mindeközben a megbízói oldalon felértékelődtek az ügyféltranzakciók adatai, az ezekből kialakított adatbázisok, amelyek hosszabb időtávon tekintve a magatartást különféle mintázatok segítségével akár a magatartás előrejelzésére is alkalmassá tehetôk (lásd pl. Barabási, 2010), és ezzel párhuzamosan

- a fogyasztók a „szokásos” csatornákon (személyesen és telefonon) mind kevésbé érhetók el, a többség mereven elzárkózik a válaszadástól, a kutatási projektben való részvételtôl és emellett még el is várják a kompenzációt, ha mégis elfogadják a felkérést a válaszadásra.

A problémák, korlátok mellett a válság és a technológiai fejlődés új lehetôségeket is megnyitott a kutatók számára, igaz, ehhez teljesen új eszköztárra, múködési logikára (és ezzel együtt a profitabilitást továbbra is garantálni képes árképzésre) volt/van szükség. A marketingkutatást leginkább befolyásoló változások a fogyasztói oldalon az alábbiak Cooke és Buckley (2008) cikke alapján:

- a megosztás „élménye” a nyílt forráskód és a web2.0 megoldások térnyerésével korábban elképzelhetetlen üzleti modelleket tett sikeressé, másokat viszont tett tönkre nagyon rövid idő alatt, ami nyilvánvalóan a már jelzett fogyasztói észlelést is meghatározza az információk értékét illetôen,

- az információáramlás színterei azok az on-line közösségi platformok, amelyek a széttöredezett fogyasztói csoportokat (törzseket) újraegyesítik, ha csak átmeneti idôre is, ezért ezeken a platformokon kell megjelennie a kutatóknak is, ha hatékony adatfelvételi megoldásokat keresnek, és végül, de nem utolsó sorban

- mindazon elemzési, információfeldolgozási eszközök is ezekhez az on-line platformokhoz csatlakoznak, ráadásul ingyenesen, vagy alacsony költségen beszerezhetők, amelyek (bár erős korlátokkal, de) kezelni tudják azt a hihetetlen mennyiségú és eltérô formátumú adatot, amit a fogyasztók megosztanak egymással.

A fentiek miatt a „hatékony kutatási eszköztárat” is újra kell definiálni, ráadásul olyan keretek között, amelyben az interaktivitás, a megosztás donimál. Kérdés, hogy a korábbi idôszak kulcsfogalmai, úgymint a reprezentativitás, vagy éppen az objektivitás mennyiben vezérelhetik továbbra is - elsősorban az üzleti célú - fogyasztói kutatásokat anélkül, hogy újragondolnánk a definíciókat. 
Ehhez persze a teljes múködési modellt is újra kell tervezni, hiszen a hagyományos megoldások esetében ezek jelentették az értéklánc egyik meghatározó elemét úgy, hogy a begyújtött adat értékét a kutatók kevéssé ismerték el, az elemzésre összeállított információs bázist viszont már valódi hozzájárulásként értelmezték a kutatási folyamatban. A jövőben ez a rendszer nehezen lesz fenntartható, hiszen itt egyértelmúen megjelenik mind a megbízói oldal elvárása, mind a fogyasztói oldal megváltozott magatartása is.

\section{A változások következményei}

Az elmúlt évtized változásainak következményeként elsóként a szekunder adatok elemzése jelent meg a primer vizsgálatok mellett, vagy még inkább helyett. Ez a Simon (2015) által is említett insourcing folyamat egyik mérföldköve volt, amelyet segített az a rengeteg adat (nyom), amit a fogyasztók hagytak/hagynak maguk után a virtuális térben. A lehetőséget felismerve olyan új szereplők ${ }^{2}$ jelentek meg a kutatási iparágban, akik esetében a szekunder adatok gyújtése a standard múködési folyamat része, így csupán azok elemzésére kellett koncentrálni. Hasonlóan gazdag adatforrást jelentenek a fórumok, blogok, értékeló oldalak, de ugyanígy használható szekunder elemzésre a legtöbb közösségi médiaplatform is. A probléma itt a big data jellegből fakad, hiszen különféle formátumú adatok elemzése napjainkban még hatékonyan nem megoldható (gondoljunk csak a fogyasztók által feltöltött hihetetlen mennyiségú képre, videóra, amelyek információtartalma releváns lehet, de egyelóre legfeljebb szövegeket tudunk nagyobb mennyiségben szoftveres támogatással elemezni).

A jövő egyik nagy lehetőségeként tartják számon a kutatók azokat az okoseszközöket, amelyek folyamatosan magunkon hordva állandó adatszolgáltatást végeznek, így téve elérhetôvé a mindennapjainkhoz kapcsolódó tevékenységek részleteit (anélkül, hogy ez a fogyasztó/válaszadó aktív közremúködését igényelné).

A primer adatgyújtés újszerú, fớként technológiaalapú megoldásainak elfogadottságát, használatát méri fel minden évben a GreenBook Research Industry Trends Report, amelynek legfrissebb kiadványából emelünk ki a témához kapcsolódó eredményeket (GRIT 2015):

- Az elmúlt néhány év vizsgálatai egyértelmúen a mobileszközökre koncentráló megkérdezések dinamikus elterjedését prognosztizálják - így a legújabb GRIT-riportban is ez áll az első helyen - a gyakorlat azonban egyelőre mást mutat. A kérdőívalapú megkérdezések alkalmazásával kapcsolatosan amúgy is megosztott a szakma, részben a válaszadói hajlandóság/képesség alacsony szintje, részben pedig a magas fajlagos költségek miatt.

- Sokkal inkább kitapintható tendencia a virtuális közösségekkel való kutatási együttmúködés, legyen szó akár kérdőíves megkérdezésról, megfigyelésről, vagy éppen egyéni, vagy csoportos interjúról.

- A közösségi médiafelületeken kifejtett fogyasztói aktivitások jól mérhetôk, elemezhetôk, akár szekunder adatokként, akár irányított primer kutatásként. Az ehhez kapcsolódó szövegelemzés is nagyot fejlődött az elmúlt évtizedben, lehetôséget adva a kvalitatív adatok nagy mintán történő elemzésére.

- Az on-line kvalitatív technikák körül is inkább pozitív várakozás érződik, mintsem általánosan elterjedt használat, mégis, a mobileszközök segítségével lefolytatott kvalitatív vizsgálatok potenciálját jelentősnek értékelték a vizsgálatban részt vevő vállalati képviselők.

- Érdekes módon a múszeres megfigyelések (szemkamerás vizsgálatok, neuromarketing megoldások, arcfelismerő/-elemző rendszerek) inkább figyelemfelkeltő jelleggel múködnek, meglehetósen magas azon válaszadók aránya, akik a jövőben egyáltalán nem tervezik kipróbálni sem ezeket a technikákat.

- Több olyan kiegészító jellegú eszköz is megjelent ugyanakkor a vizsgálatban, amelyek a kérdóives vizsgálatok újragondolását, a megváltozott kereteknek való jobb megfelelést célozzák. Ilyen például a mikrokérdő́vek és a gamification fejlesztési irány is, amelyek mindegyike a válaszadói hajlandóság javítására tesz kísérletet.

- A virtuális valósághoz kapcsolódó eszközök, valamint a napjainkban divatos alternatív irányzat, a viselkedés-gazdaságtan beemelése a vizsgálatba újdonság, várható elterjedésük azonban inkább csak közepes valószínúséggel bír a felmérés szerint.

- Új kutatási irány a hordható okoseszközök által rögzített megfigyelési adatok vizsgálata. Habár a szakma megosztott a megoldások potenciálját illetôen, a szenzorok által rögzített viselkedési adatok térnyerése megítélésünk szerint nem megkérdőjelezhetô.

Összességében tehát igazolódni látszik Simon (2015) megállapítása, miszerint a megfigyeléses módszerek technológiai fejlesztése előtérbe helyezi a valós magatartás elemzését, amely mellett azonban továbbra is az alapvetően kérdőíves megkérdezések technikai átalakulása zajlik a fogyasztók által leggyakrabban használt platform(ok)nak megfelelóen. 


\section{Összegzés}

A marketingkutatás területén belül is jelentôs átalakulások mentek végbe az elmúlt egy-másfél évtizedben. Ennek hatására teljesen új üzleti és múködési modellek jelentek meg, amelyek képesek megfelelóen kielégíteni a megbízói oldal újrastrukturált igényeit.

Alapvető mozgatórugója a folyamatoknak a technológia, amihez társult a gazdasági válság kényszerítő ereje. E két hatás eredőjeként jelentek meg az iparágban olyan új, innovatív megoldások, amelyek költséghatékonyan, rövid idő alatt a lehetőségekhez mérten objektív információkat tudnak szolgáltatni a döntéshozatalhoz.

A változások folyamatossá váltak, ezért jelen tanulmány keretei között inkább csak felvillantani tudtuk azokat a fontosabb irányokat, amelyek a marketingkutatás módszertani átalakulását meghatározzák. Mivel a tanulmány célja az üzleti célú marketingkutatások esetében lezajlott, vagy folyamatban levő változások áttekintése volt, ezért nem tértünk ki az akadémiai fókuszú kutatásmódszertan változására. Nyilvánvaló ugyanakkor, hogy ezen a téren is átalakulások mennek végbe, még ha az előzőekben bemutatottaktól részben eltérő irányokkal és sebességgel is.

\section{Lábjegyzet}

${ }^{1}$ A korábbi tanulmányokban (pl. Törőcsik - Szúcs, 2014; Szúcs, 2014) vázolt közelítés továbbfejlesztése történik meg jelen cikk keretei között.

${ }^{2}$ Ilyen új szereplő például a Tesco és a Google is.

\section{Felhasznált irodalom}

Barabási Albert-László (2010): Villanások. Budapest: Libri Könyvkiadó

Chadwick, S. (2006): Client-driven change: the impact of changes in client needs on the research industry. International Journal of Market Research, 48(4): p. 391-414.

Cooke, M. - Buckley, N. (2008): Web 2.0, social networks and the future of market research. International Journal of Market Research, 50(2): p. 267-290.
Fletcher, W. (2006): The splintered society. International Journal of Market Research, 45(3): p. 387-388.

Gordon, W. (2006): Out with the new, in with the old. International Journal of Market Research, 48(1): p. $7-25$.

GRIT (2015): The GreenBook Research Industry Trends Report. 2015 Q1-Q2. https://www.greenbook.org/grit

Grover, R. - Vriens, M. (2006): The Handbook of Marketing Research: uses, misuses and future advances. London: Sage

Malhotra, N. K. - Simon J. (2009) Marketingkutatás. Budapest: Akadémiai Kiadó

Malhotra, N. K. - Peterson, M. (2001): Marketing research in the new millennium: emerging issues and trends. Marketing Intelligence \& Planning, Vol. 19 Iss: 4: p. $216-232$.

Simon J. (2016): Kutatás-módszertani trendek a marketingben. in: Marketingtudományi Évkönyv. Budapest, megjelenés alatt

Szuйcs, K. (2013): A (környezet)tudatosság és a válaszadási hajlandóság összefüggései. Via Futuri Konferencia 2013, Pécs, 2013. November 28 - 29. Pécs: PTE KTK Kiadó

Szúcs K. (2014): Válaszadási hajlandóságot befolyásoló attitúdök. in: Hetesi Erzsébet - Révész B. (szerk.): Marketing megújulás: Marketing Oktatók Klubja 20. Konferenciája. Konferencia helye, ideje: Szeged, Magyarország, 2014.08.27-2014.08.29. Szeged: SZTE GTK

Törö́csik, M. (2011): Fogyasztói magatartás. Insight, trendek, vásárlók. Budapest: Akadémiai Kiadó Zrt.

Törö́csik M. - Szücs K. (2014): Marketingdilemmák a fogyasztó megismerése során. in: Rappai Gábor Schepp Zoltán (szerk.): Válságtól a jóllétig: A múlt tanulságai, a jelen kihívásai és a jövő útjai. Pécs: Pécsi Tudományegyetem Közgazdaságtudományi Kar: p. 215-244.

Zolli, A. (2006): Recognizing Tomorrow's Hot Ideas Today. BusinessWeek, 9/25/2006 